Historic, Archive Document

Do not assume content reflects current scientific knowledge, policies, or practices. 



\section{SUPERB PEONIES}

\section{FALL 1929 .. SPRING 1930}

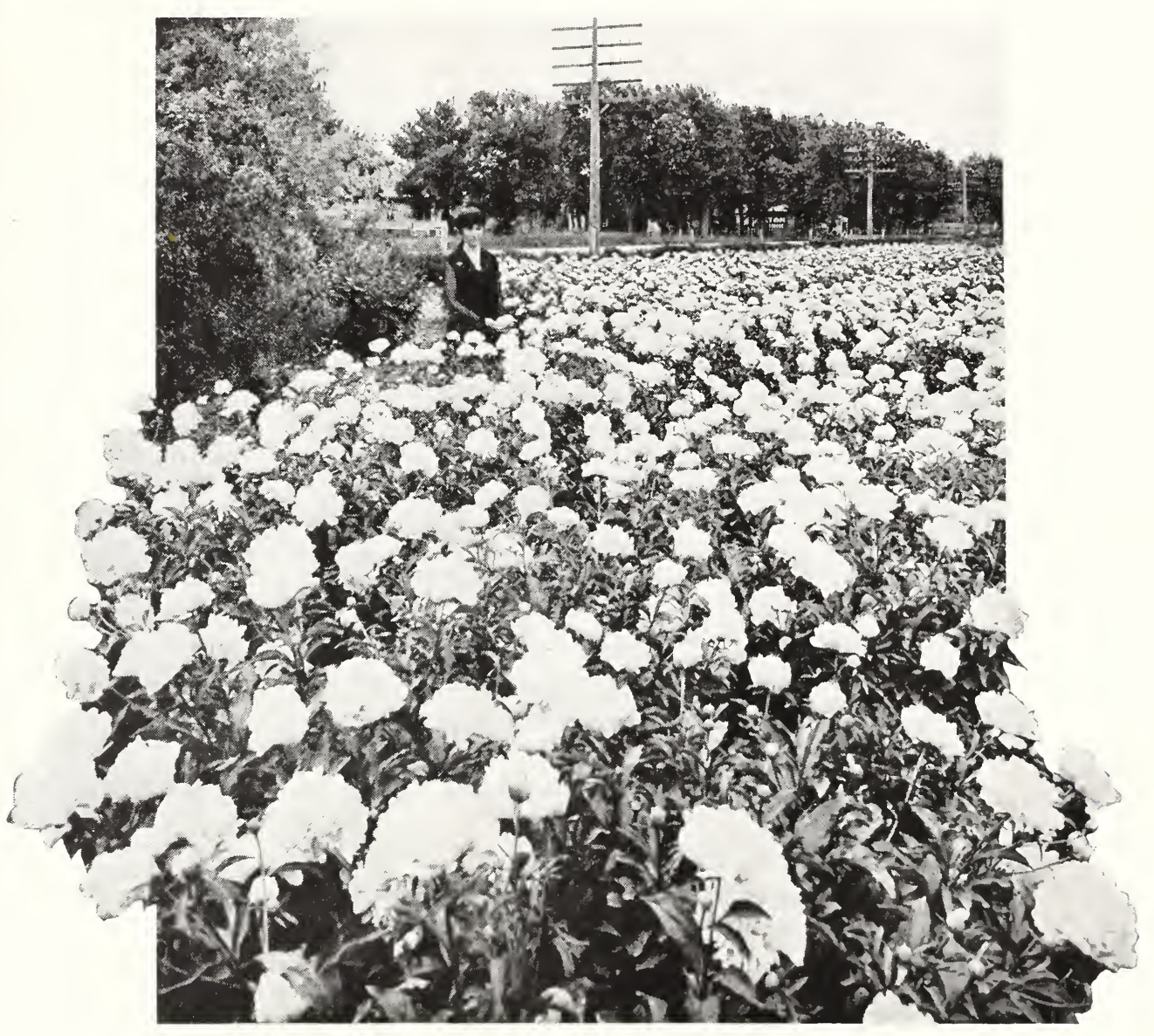

\section{Roseinelal Peony Gardens}

RENO ROSEFIELD, OWNER WEST GRAND AVENUE
ROAD

Des Moines, Iowa

MAIL ADDRESS, VALLEY JUNCTION, IOWA 
The object of this booklet is to encourage interest in and knowledge of modern peonies, and to offer herein a choice collection of the world's best. These varieties have been carefully selected over a period of more than forty years from practically all the world has had to offer in peonies, close to two thousand varieties.

The prices for this season have been made as reasonable as is possible, consistent with the highest grade of stock, and there is no higher quality stock offered anywhere.

Special collections of varieties have been compiled for your convenience and if any of these collections should particularly fit your needs it will mean an opportunity to get a start with choice peonies at greatly reduced prices. Please bear in mind that some of the best varieties go to make up the collections and the quality is all highest class.

It is easy to order from this catalog and this means it makes no difference how far away you may be, the peonies will reach you in first class shape and prove satisfactory. The main thing is to plan eirly to plant as generously of this grand flower as your means and garden space will admit, place your order early, and get started right. You will never regret it. A permanent hardy garden of peonies will mean a source of health and enjoyment to you and a wealth of beauty to the spot that is your home for many years to come. 


\section{Atlodern 羽onies}

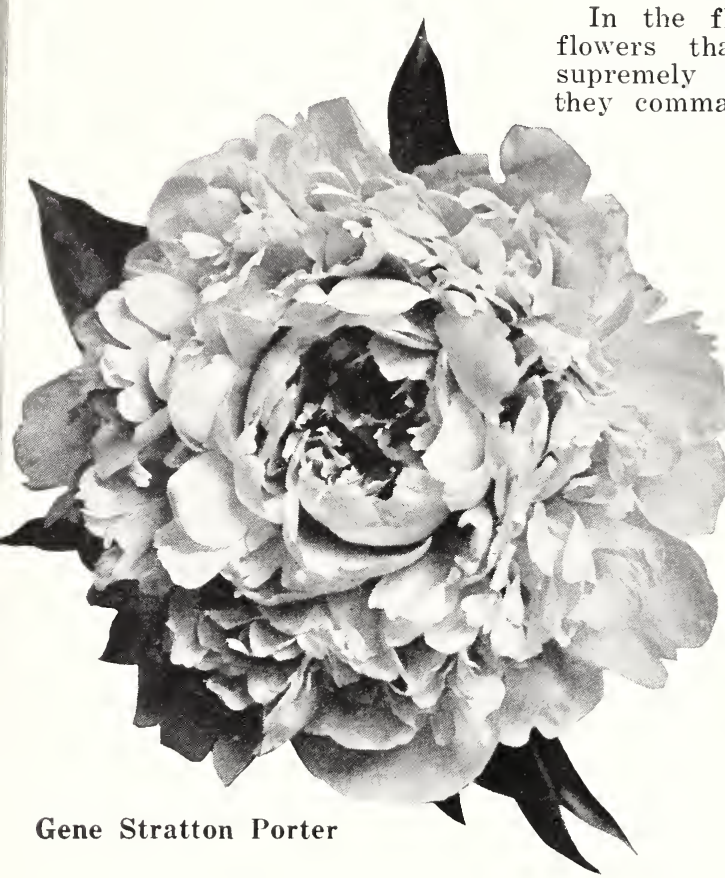
der greenhouse culture, but we can ALL grow peonies to perfection. Every home that has a little garden space should have flowers and every garden of flowers should contain a good planting of choice peonies.

It is perhaps pretty generally known that peonies are one of the most permanent of the hardy perennial plants, that the plants grow in size and beauty as well as value as the years go by. They need not be moved or disturbed for ten to fifteen years after they are once planted and often, under good care, they have been known to give very satisfactory results in the same location for more than twenty-five years.

Many of the newer improved varieties are beautiful beyond the imagination of those who are not familiar with them, and since many of these can now be secured at reasonable prices they should be more freely planted. Therese is generally considered one of the finest pinks and is now very reasonable in price. The same is true of many other beautiful varieties such as Karl Rosefield, Lady A. Duff, La France, La Perle, Longfellow, Mme. Jules Dessert, Marie Crousse, Martha Bulloch, Reine Hortense, Richard Carvel, Sarah Bernhart, Solange, Tourangelle, Walter Fason and many others. It is really difficult for many to see much difference between the quality of the above and some of those rare varieties priced at from $\$ 10.00$ to $\$ 50.00$ or more. The reason for the high price of many varieties of peonies is due to the fact that they are of very recent introduction and are very scarce. Some few varieties are slow to increase and if they are also of very high quality the price will remain fairly high for many years. This is true of Milton Hill for 
example which came into existence some forty years ago and to this day the stock is scarce. This variety will stand with the best of the pinks in sheer beauty. This variety as well as others in its class are well worth their cost, and like all good things will return to their owners many times the value of their cost in satisfaction long after the cost is forgotten. It costs no more in care and space to keep a good peony than a poor one and the first cost of good peonies is usually not a great deal greater than poor or indifferent ones. Let us all, therefore, plan our gardens with a quality that is in keeping with our standard of quality in other things that enters into our lives and our homes.

On the pages that follow you will find a list of choice peonies that you can depend on to give satisfaction in every way and you can also depend on us to do everything possible toward making your purchases of peonies of us pleasing to you in every way. Rosefield's Superb peonies have satisfied thousands of others in all parts of the country for the past forty years. We can satisfy you. May we hear from you?

Before bringing this to a close we wish to extend herein to every flower lover an invitation to visit our Peony Gardens, especially during the blooming season which is usually from the last of May until about the 20 th of June. The Rosefield Peony Gardens is one of the large peony gardens of the country and during the blooming season a real treat is in store for every visitor. The gar dens contain more than three hundred different varieties of choice peonies and the number of plants is well over a hundred thousand. Special plantings of choice cutflower varieties are maintained especially for cutflower production and little or no cutting of tlowers is made from the plants grown for sale. Peony blossoms of unusual beauty may be obtained throughout the blooming season at reasonable prices.

\section{羽ony Callections}

The following collections are made up of some of the choicest and most dependable varieties in their respective price classes and should prove very popular. These collections will each give a well balanced peony planting in a range of colors.

Please order these collections by number and please do not request changes in the varieties composing them.

\begin{tabular}{lcc}
\multicolumn{3}{c}{ Beginners Collections } \\
Festiva Maxima
\end{tabular}

\section{COLLECTION NUMBER ONE}

This is an inexpensive collection of very good peonies in a good range of color.

Mme d Verneville. White ............................................................. \$1.00

Couronne d Or. White ..................................................................... 1.00

James Kelway. Light Pink ............................................................... 1.50

Mons. Jules Elie. Pink ..................................................... 1.50

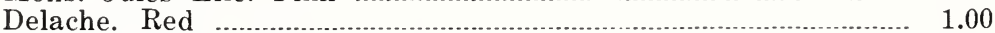

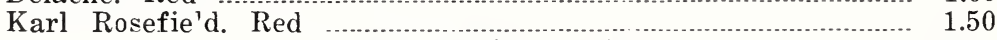

\section{The Collection for $\$ 5.00$ \\ $\$ 7.50$}

\section{COLLECTION NUMBER TWO}

This gives about the widest range of color it is possible to get in peonies, from white to darkest crimson. The varieties in this collection are all high class.

Mme. Jules Dessert, Blush White ............................................\$2.50

Baroness Schroeder, White ........................................................... 1.50

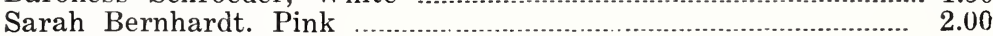

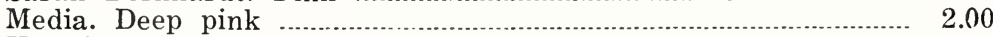

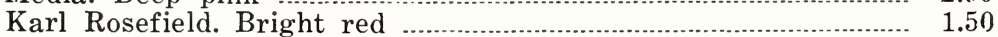

M. Martin Cahuzac. Dark crimson .............................................. 2.50

The Collection for $\$ 8.00 \quad \$ 12.00$ 


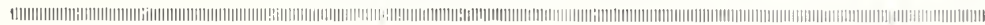

\section{COLLECTION NUMBER THREE}

This collection gives the widest range of blooming season in each of the following colors, white, pirk and red.

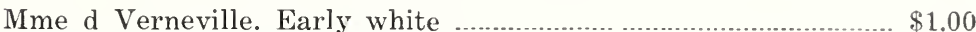

Couronne d Or. Midseason white ……......................................... 1.00

Marie Lemoine. Late white ..................................................... 1.50

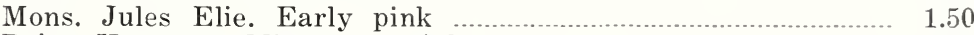

Reine Hortense. Midseason pink …....................................... 2.00

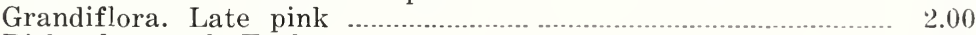

Richard Carvel, Early red ............ 3.00

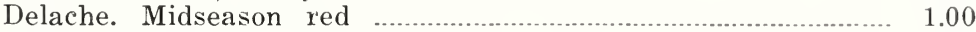

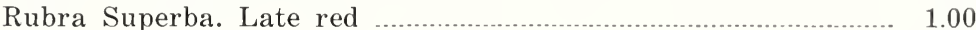

The Collection for $\$ 10.00 \quad \$ 14.00$

\section{COLLECTION NUMBER FOUR}

This is the largest and best collection of good inexpensive peonies we could select. There are twenty two varieties in the list and everyone are good.

Adolphe Rousseau, Deep crimson ……................... $\$ 1.50$

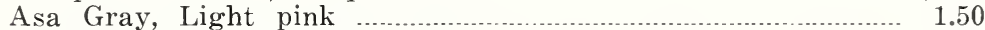

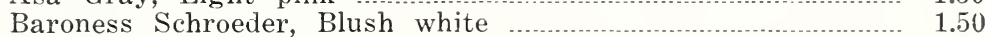

Couronne d Or, White 1.00

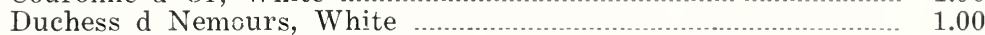

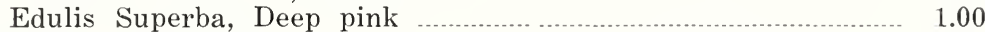

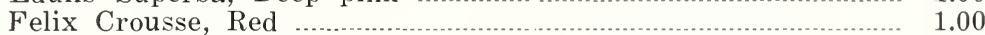

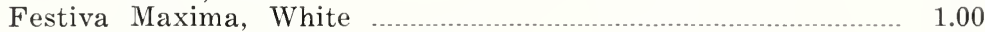

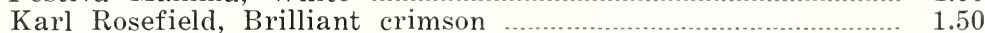

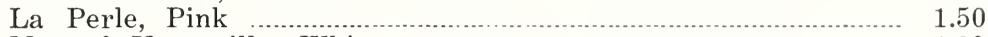

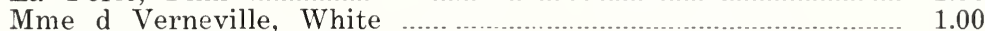

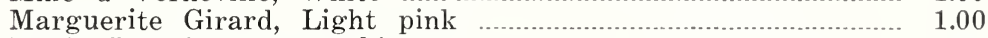

Marie Lemoine, Late white _............................................. 1.50

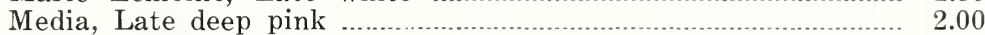

Mons. Dupont, White 1.00

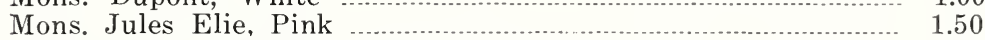

Mons. Martin Cahuzac, Crimson maroon ……........................... 2.50

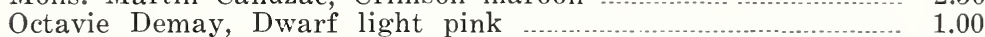

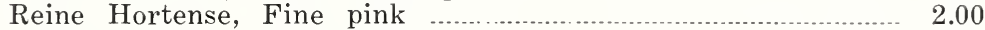

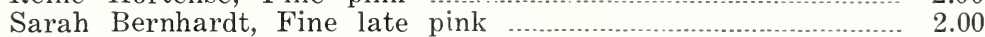

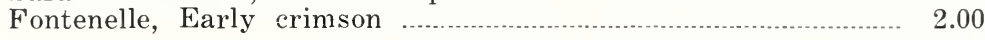

The Collection for $\$ 20.00 \quad \$ 30.00$

\section{COLlection NUMBER fIVE}

This collection embraces a dozen very high class varieties. The prices are very moderate considering quality. The collection will make a peony garden anyone can be proud of.

Karl Rosefield, Deep red ……………………....................... \$1.50

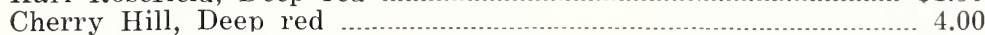

Longfellow, Bright red ……_............... 3.00

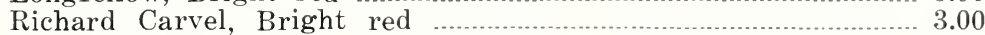

Martha Bulloch, Pink ...................

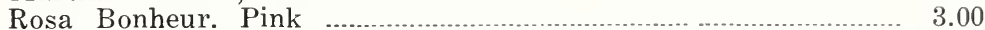

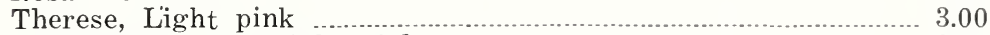

Tourangelle, Very light pink ….................................................. 3.00

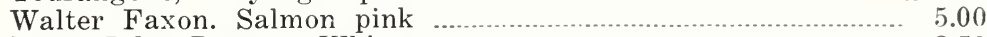

Mme. Jules Dessert, White 2.50

Primevere, Yellow and white

Solange, Amber white …...................................................... 3.50

The Collection for $\$ 30.00 \quad 40.00$ 


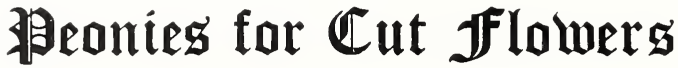

Peonies may serve a double purpose during the period of their blooming; that of beautifying the garden and that of supplying an abundance of cut bloom for the home.

In cutting peonies, care should be exercised not to cut the stems so long as to remove all foliage from the remaining stem. From two to three leaves should be left on each stem from which flowers have been cut, in order that the roots and eyes may be properly developed for the following season.

Among the chief charms of many peonies like Laura Dessert, Mme. Jules Dessert, Primevere, Solange, Therese, Tourangelle and Walter Faxon are the delicate color tones of their blossoms. These are sometimes lost by fading out if the blossoms open in the full sunlight, but may be preserved by cutting when they have developed to the stage of the opening bud, placed in cool water, and allowed to open in the shade in a room of the house.

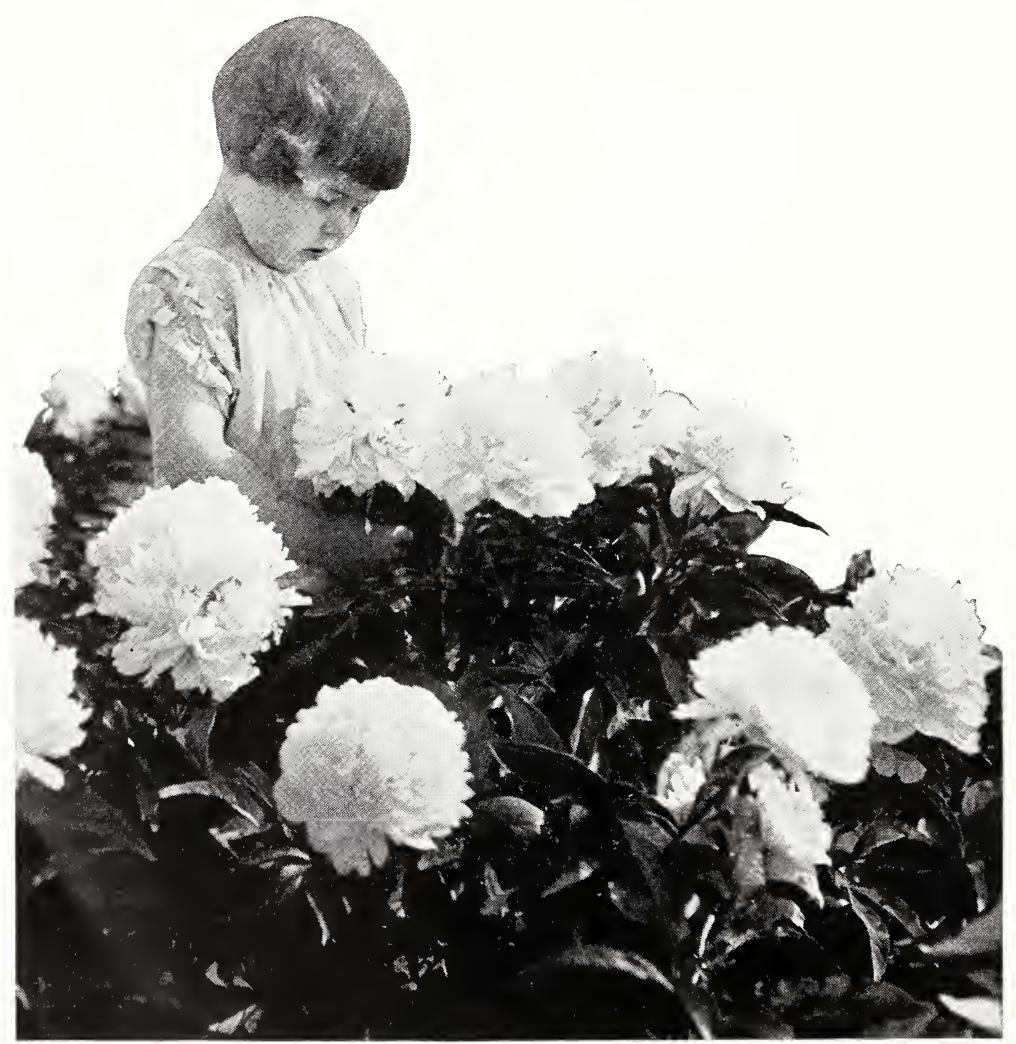

Little Annabelle Stewart and Couronne d' Or 


\title{
THE
}

\section{Rosefield 羽ony Gardens}

\author{
BRIEF HISTORICAL NOTES
}

The Rosefield Peony Gardens is an individual enterprise, originally established at West Point, Nebraska, in 1884, by Mr. J. F. Rosefield.

Moved from West Point to Omaha, Nebraska in 1910 and located on the West Dodge Street road, operating at this location until the close of 1917 , when land was sold, together with a part of stock planted for cut-flower production. Choicest varieties were reserved and moved to 72nd \& Bedford Ave., Omaha.

Management of business and stock passed from father to son in 1919 and the Rosefield Peony gardens are owned and operated by Reno Rosefield at the present time.

The location at 72nd \& Bedford Ave., Omaha was found inadequate to meet the needs of the business in its present capacity, necessitating another move.

The present location of the Gardens is directly west of Des Moines, Iowa, on the West Grand Avenue road or Federal Highway No. 32; being the main highway from Omaha to Chicago thro Des Moines. The new farm is very easy to locate and all persons interested in peonies are welcome to come and enjoy or study them.

\section{羽eoníes}

\section{BRIEF INSTRUCTIONS ON PLANTING AND CARE}

The peony is absolutely hardy and if properly planted in congenial soil and given reasonable care is sure to thrive and give its wealth of beauty year after year.

\section{LOCATION AND SOIL}

First, choose a well drained location as peonies will not thrive on wet or marshy soil. Any good garden soil will do if not too rich. Clay loam is excellent. Avoid, if possible, potato land or ground on which potatoes have recently been grown. Open sunlight or partial shade is to be preferred to a totally shady location. If possible prepare the ground some time in advance of planting. Dig down and loosen the soil to a depth of 12 to 18 inches. Peonies will pay for the little extra pains taken for their welfare.

\section{PLANTING}

When the roots arrive dig holes deep enough to hold them in an upright position, with the eyes two inches below the surface. Be sure to place the roots so the eyes are on the upper end when planted. Fill in around the roots with good clean soil, no manure, and pack firmly. If soil is dry at time of planting give a good soaking of water after planting is done. Use no fresh manure in any form or manner.

\section{AMERICAN PEONY SOCIETY}

Your enjoyment of peonies will be much enhanced if you are a member of the American Peony Society and receive the bulletins and literature of the Society. Fall information will be sent on request. 


\section{General Instructions}

\section{ORDERS}

Please make your selection and send your order in as early as possible. September and October are the best months in which to plant peonies. Be sure to write your name, postoffice, county and state very plainly, also express office, if different from postoffice.

\section{SHIPMENTS}

We have found express to be the safest and most reliable method to ship peonies and all shipments will be made this way unless instructed otherwise or unless the quantity ordered should be heavy enough to make freight shipment advisable.

\section{TERMS}

Cash with order unless special terms have previously been arranged. Please make remittance by personal check, postoffice or express money order or bank draft. It is unsafe to send cash or currency through the mail, even in registered letters.

The roots we will send out on your order will be first class, strong, healthy natural divisions with three to five or more eyes. There is no size that will do better for you and we always send the size that will do the best possible for our customers. Do not plant large clumps two or more years of age without first separating them, they will never bloom well if you do. The natural divisions we send out will become established quicker and do better than any other size. Small divisions will usually grow and become established but it takes longer and the risk of loss is greater. We do not send out the small one to two eye divisions.

\section{ROSEFIELD PEONY GARDENS}

Reno Rosefield, Owner

West Grand Avenue Road

DES MOINES, IOWA.

MAIL ADDRESS

ROUTE 1, VALLEY JUNCTION, IOWA 


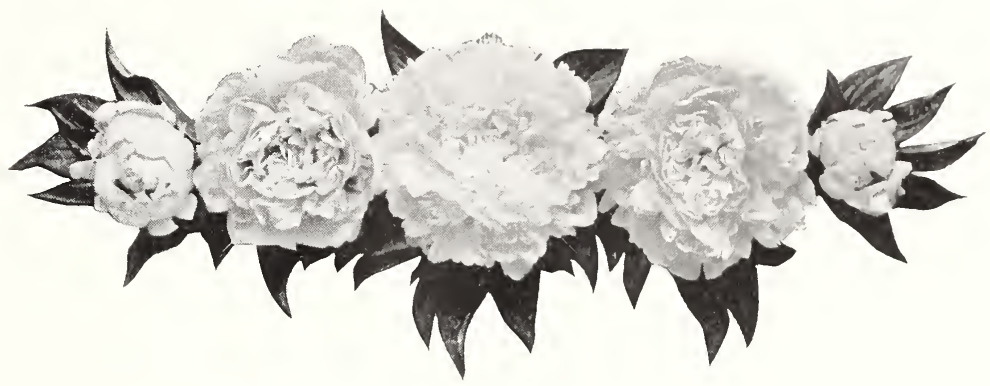

\section{Quality liating}

The rating of the various varieties as shown was established by a vote of the members of the American Peony Society in 1919, 1921 and 1925.

The rating is based upon a scale of 10 which represents the highest excellence; 9 high quality; 7 to 8 good quality; while below 5 is to be considered unworthy of cultivation.

These rating figures will serve as a guide in determining the quality of almost any variety under consideration. There are a few varieties, however, that I think should have received a higher rating and a very few a little lower. However, on the whole it is the best and only guide to quality we have in published form.

The scale of points adopted by the American Peony Society and upon which the rating should be based is as follows:

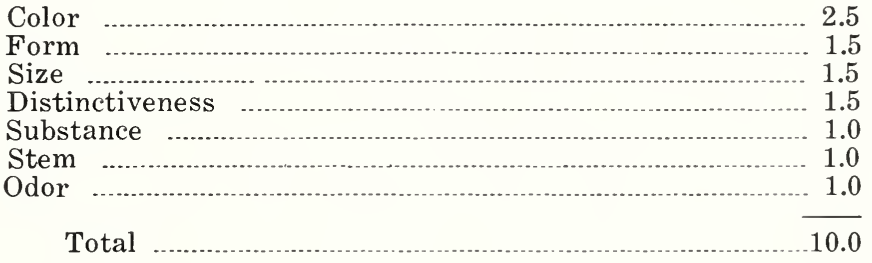

For blooms without odor ……………................................. 0.5

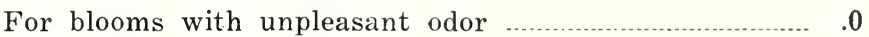

The rating figures follow the name of the variety. The first figure denotes the number of votes cast and the other figures the result. For instance: ADOLPHE ROUSSEAU, 56-8.5 denotes the variety received fifty-six votes and is rated at eight and five-tenths.

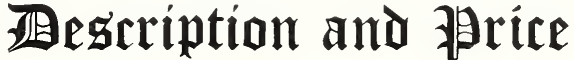

\section{ADDELANCHEA (Brand)}

Creamy white. Pose type. Fragrant. Late midseason bloomer.

Each $\$ 6.00$

ADOLPHE ROUSSEAU (Dessert \& Mechin)

$56-8.5$

Very dark velvet red with garnet hues and metallic reflex. Semidouble with large shell like petals. Early midseason. Tall and erect. 
Delicate shell pink. Bomb type; large, full and well developed. Fragrant profuse bloomer. This flower somewhat resembles a carnation in its formation.

Each $\$ 1.00$

ALFRED DE MUSSET (Crousse 1885)

$19-7.4$

Flesh white with a blush center and crimson flecks. Semi-rose type. Beautiful variety with slender stems. Medium height. Early midseason.

Each $\$ 1.00$

ALSACE LORRAINE (Lemoine 1906)

$41-8.8$

Cream white, center delicately tinted buff. Rose type and of a form suggestive of a water lily. Distinct and beautiful. Each $\$ 3.00$

\section{ARLEQUIN (Dessert 1921)}

Broad guard petals clear purplish pink splashed silvery white; center, salmon, pink and yellow. Variable in form and tint. Many flowers from side buds are of Japanese type; main flowers full double.

Each $\$ 1.50$

\section{ASA GRAY (Dessert 1921)}

$59-8.1$

Pale lavender pink delicately dotted carmine. Large, massive and compact fragrant bloom imbricated like a rose. Of refined appearance. Erect, medium height. Midseason, profuse bloomer of great beauty.

Each $\$ 1.50$

ASSMANSHAUSEN (Goos \& Koenemann 1912)

$3-8.0$

Pure white, large loose flower of flat rose type. Fragrant late bloomer.

Each $\$ 2.00$

\section{AUGUSTE DESSERT (Dessert 1920)}

Velvet crimson carmine with silky reflex and often streaked white; silver border on petals. Distinct cup shaped flower. This peony is distinct in color and is getting to be quite a prize winner.

Each $\$ 8.00$

\section{BARONESS SCHROEDER (Kelway 1889)}

$79-9.0$

Flesh white, sometimes light pink on first opening, fading to pure white. Rose type. Delightfully fragrant. Late. Valuable as a commercial cutflower variety. Of good substance and keeping quality and one of the most beautiful and valuable white peonies in existence.

Each $\$ 1.50$

CHARLES McKELLIP (Brand 1907)

$20-7.8$

Crimson, intermixed with golden stamens. Semi-rose type of good form.

Each $\$ 2.00$

\section{CHARLOT (Doriat 1924)} stems.

Silvery lilac, carmine base, broad silvery border. Strong erect

CHERRY HILL (Thurlow 1915)

$24-8.6$

Deep garnet with visible stamens. Tall erect grower. Early bloomer.

Each $\$ 4.00$

Silvery pink outer petals, center deeper. Classed as crown type, the flower develops into a striking cone shape. F'ragrant. Midseason to late.

Each $\$ 1.00$ 
Rich clear satiny pink delicately tinted lavender and overlaid with a sheen of silver. Rose type. Large globular flower with petals incurved, overlapping each other in a charming way. Described by some as a glorified Mons. Jules Elie. Our stock is clean, strong and healthy.

Each $\$ 1.50$

\section{CLEMENCEAU (Dessert 1920)}

Carmine, slightly shaded amaranth, with silvery tints and wide silver border. Large, full imbricated bloom. Very late. Each \$6.00

COURONNE D'OR (Calot 1873)

$67-8.1$

White, slightly flecked crimson, reflecting golden stamens thro the petals. Late mid-season; profuse bloomer and very desirable and popular.

Each $\$ 1.00$

\section{DELACHEI (Delache 1856)}

$43-7.1$ season.

Rich violet crimson. Good bloomer when established. Late mid-

\section{DUCHESS D NEMOURS (Calot 1856)}

Each $\$ 1.00$

Sulphur white without flecks except a touch of green at the heart that seems to light up the whole flower. Beautiful in the opening bud. Fragrant. Early. Medium to large flowers.

Each $\$ 1.00$

\section{DUKE OF WELLINGTON (Calot 1859)}

$46-7.8$

White, bomb type. An old variety still popular and considered for the sulphur yellow cast of its color upon first opening. Each $\$ 1.00$

\section{EDULIS SUPERBA (Lemon 1824)}

$66-7.6$

Bright clear deep pink. Very early and fragrant as a rose. Free bloomer. Used extensively for Memorial Day cut-flowers. Each $\$ 1.00$

\section{EDWIN C. SHAW (Thurlow 1919)}

Clear shell pink. Outer petals broad and rounded, sometimes slightly edged crimson. Petals nearly the same length except center petals are short giving the flower an elegant cup-shaped form.

Each $\$ 15.00$

\section{ELLA CHRISTINE KELWAY (Kelway 1899)}

Flesh pink of even tint. Large, compact globular flower of beautiful form and color. Free bloomer. Exquisitely fragrant. Midseason.

Each $\$ 2.00$

E. G. HILL (Lemoine 1906)

$28-7.8$ clusters.

Rose red, semi-rose type. Early midseason. A good bloomer in

\section{E. J. SHAYLOR (Shaylor 1918)}

Each $\$ 2.50$

Globular compact bloom of rose pink petals tipped lighter. This variety is distinct because of the ring of golden edged and golden tipped petals. Strong upright stems of medium height. Midseason to late

Each $\$ 8.00$

ELWOOD PLEAS (Pleas 1900)

$36-8.7$

Beautiful shade of shell pink. Flat, compact flower of fine form. Upright grower and good bloomer. A very lovely peony. Each $\$ 2.00$

Cream white with guard petals splashed crimson. Center slightly flecked crimson and faintly illuminated with a reflex of green. Fragrant, tall, erect and late. This is a gorgeous peony when the season is favorable for its best development.

Each $\$ 3.00$ 


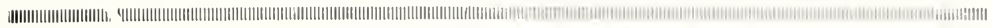

$$
\text { DES MOINES, IOWA }
$$

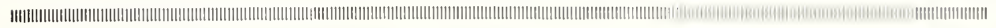

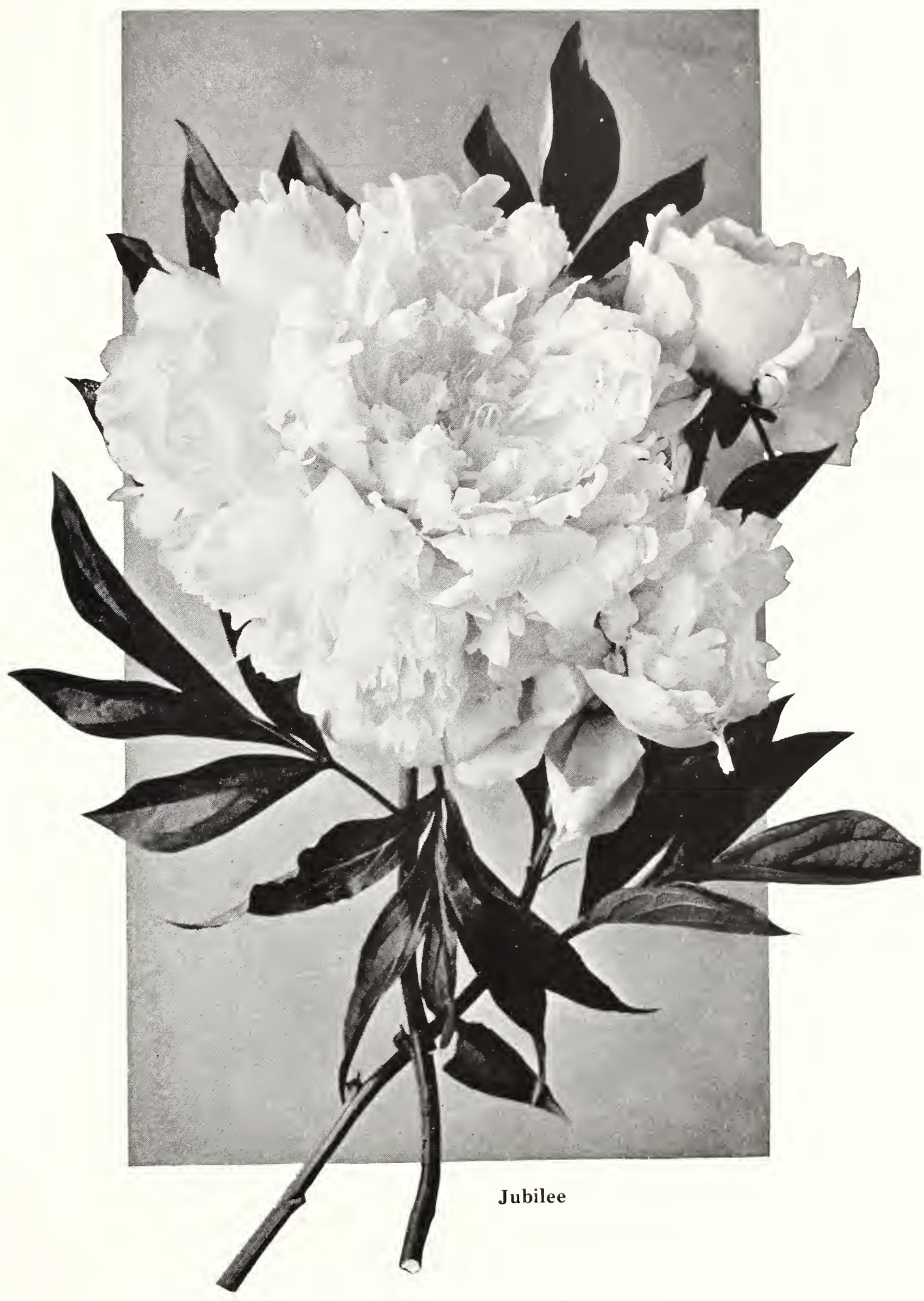



Late

Hydrangea pink. Rose type. Large, fragrant showy variety.

\section{EUGENE VERDIER (Calot 1864)}

Each $\$ 1.50$

Light hydrangea pink center deeper with yellow tints. Erect strong grower. Medium height. Midseason Each $\$ 1.50$

SUGENIE VERDIER (Calot 1864)

$58-8.6$

Fresh delicate hydrangea pink. Semi-rose type. Tall, graceful variety with beautiful flowers. Do not confuse with Eugene Verdier.

Each $\$ 1.50$

\section{EXQUISITE (Kelway 1912)}

Deep rosy pink. Flat flowers showing vellowish anthers in center. Semi-double. Beautiful flower of beautiful color.

Each $\$ 3.00$

FELIX CROUSSE (Crousse 1881)

$75-8.4$

Bright ruby red of even shade. Bomb type. A good commercial cut-flower red. Good keeper. Early midseason.

Each $\$ 1.00$

FESTIVA MAXIMA (Miellez 1851)

$84-9.3$

Pure white, center flecked crimson. Rose type. Extra large, showy perfect flowers. Tall strong and erect. Very popular. Each \$1.00

\section{FLORENCE MACBETH (Sass 1924)}

Light pink, deepening toward center. Rose type. Flat flower of fine shape. Good strong stems. Very desirable.

Each $\$ 15.00$

\section{FONTENELLE (Rosefield 1916)}

Clear brilliant crimson. Semi-rose type. This variety is as yet little known. It posseses to an extraordinary degree the qualities of a good commercial cut-flower. Long, strong graceful stems; flowers medium size, not too heavy, and of extra good keeping qualities. Early bloomer.

Each $\$ 2.00$

\section{FRANCES SHAYLOR (Shaylor 1915)}

Glistening waxy creanı white petals intermixed with canary yellow stamens. Dwarf plant. Midseason.

Each $\$ 4.00$

\section{FRANCES WILLARD (Brand 1907)}

$31-9.1$

Blush white changing to pure white with an occasional touch of carmine. Semi-rose type of fine form. Late midseason, free bloomer. Very good.

Each $\$ 3.00$

\section{FRANCOIS ROUSSEAU (Crousse 1909)}

Brilliant rich crimson, deep in color and yet bright. Semi-rose type flower of very fine form especially when well grown. A very good, fragrant, early red that we think is somewhat under rated.

Each $\$ 2.00$

\section{GENE STRATTON PORTER (Rosefield 1925)}

Pure immaculate white. Rose type. Cup-shaped with fine incurving petals growing shorter toward the center. Strong upright grower. free bloomer. See cut page three.

Each $\$ 20.00$

\section{GEORGIANA SHAYLOR (Shaylor 1908)}

$29-8.9$

Pale rose pink with a few flecks of crimson. Flower large and somewhat flat. Dwarf strong grower. Late midseason. Each $\$ 4.00$

GERMAINE BIGOT (Dessert 1902)

$46-8.5$ er.

Pale lilac rose, center flecked crimson. Midseason. Free bloom-

\section{GIAN'T (Kelway)}

Deep pink. Rose type, perfect, rather flat flowers of large size. High class. 


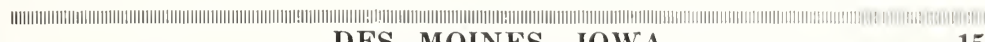

DES MOINES, IOWA

15

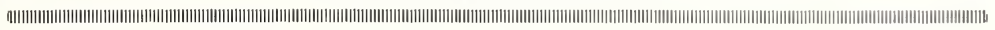

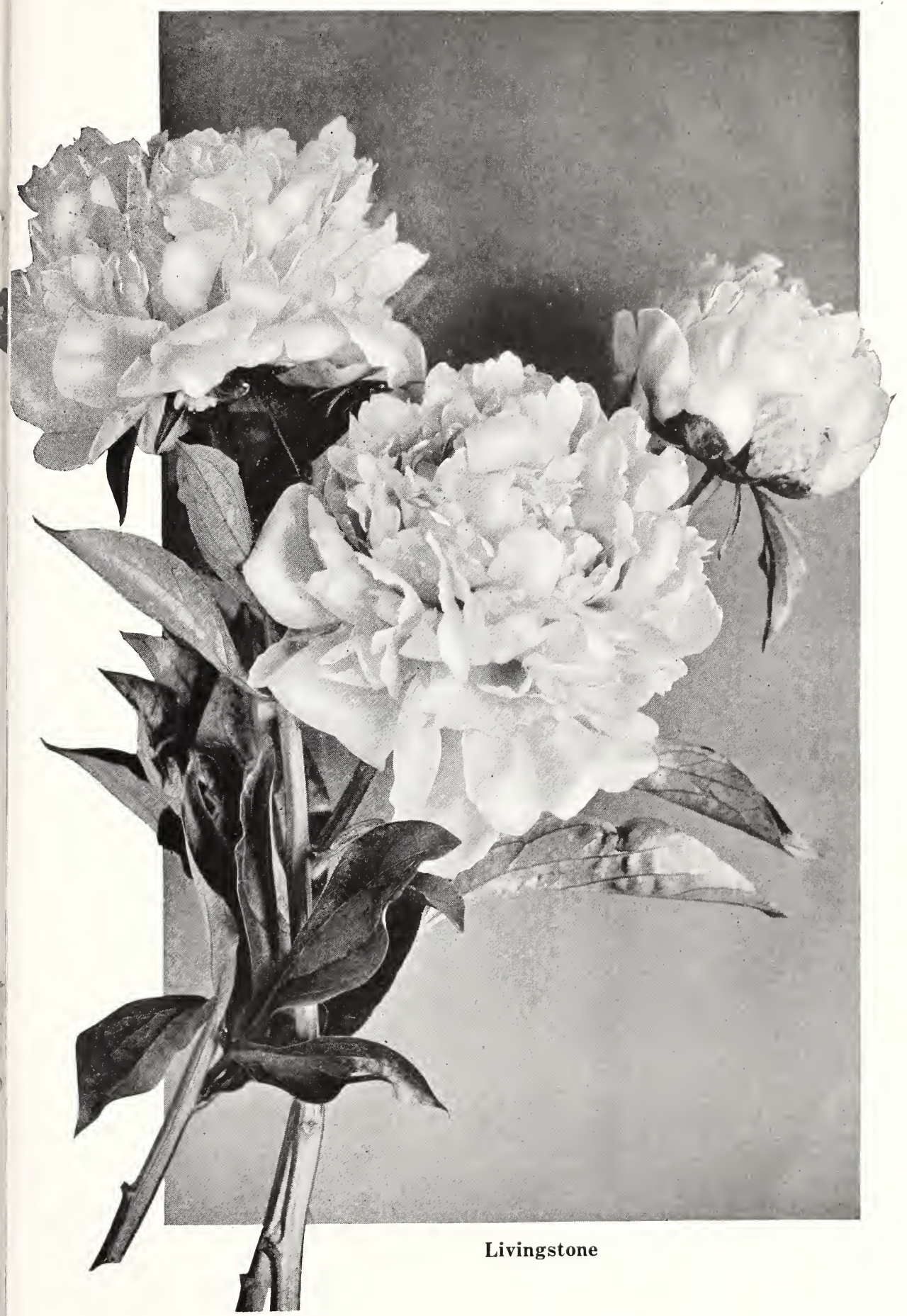




\section{GINETTE (Dessert 1915)}

Soft flesh pink with salmon tints at base of petals. Rose type. Fragrant free bloomer. Imbricated, cup shaped flower of great beauty.

Each $\$ 3.00$

\section{GISMONDA (Crousse 1895)}

Flesh pink deepening to rose toward the center. Full double flowers. A charming late variety. Fragrant.

Each $\$ 1.50$

GRANDIFLORA (Richardson 1885)

$62-8.8$

Bright shell pink overlaid with delicate shades of lilac and salmon. Beautiful rose type. Very late.

Each $\$ 2.00$

GROVER CLEVELAND (Terry)

$39-8.2$

Brilliant bright crimson. Rose type. Late midseason. Each $\$ 1.50$

\section{HARRY L. RICHARDSON (Rosefield 1925)}

Clear deep bright red or crimson. Full rose-type. Perfect in form. Possesses an unusually sweet rose fragrance seldom met with in red peonies. Very late; blooming at the same time as Rubra Superba but unlike Rubra Superba, this variety is free blooming; opening its flowers in perfect shape. Fills a long felt need for a free blooming, late red peony.

Each $\$ 25.00$

\section{HAZEL KINNEY (A. M. Brand 1925)}

Uniform hydrangea pink, color delicate and pure. Profuse bloomer. Large sized flowers. Late bloomer.

Each $\$ 50.00$

\section{HELEN WOLAVER (Brand 1918)}

Shell pink, guard petals splashed with deeper pink. Rose type. Resembles a rose in the bud. Unique.

Each $\$ 2.00$

HESPANOLA (Andrews 1923)

Deep uniform shell pink shaded deeper. Large full rose type. Free bloomer. Late.

Each $\$ 6.00$

\section{INSPECTEUR LAVERGNE (Doriat 1924)}

Vivid crimson, frilled petals in the center. Very full, fine globular flower. Beautiful variety with abundant bloom. Each \$20.00

\section{ISOLENE (Lemoine 1916)}

Cream white, center tufted deep straw yellow. Rose type cup shaped flower. A good near yellow.

Each $\$ 1.00$

\section{JAMES KELWAY (Kelway 1900)}

White, overlaid with a delicate flush of pink and a touch of yellow at the base of petals. Large, fragrant, semi-rose type flower. Early midseason free bloomer.

Each $\$ 1.50$

\section{JAMES R. MANN (Thurlow 1920)}

Large, deep rosy pink, with one or two crimson streaks in the center of the flower and an occasional marking on back of guard petals. Center petals incurved, giving the flower a very graceful effect. Midseason. 


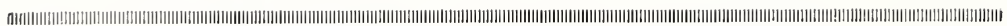
18 THE ROSEFIELD PEONY GARDENS

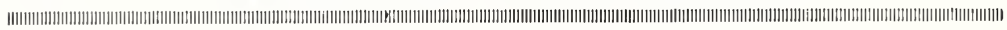

\section{JEANNOT (Dessert 1918)}

Flesh pink, with lavender tints and shaded salmon at base of petals, changing to silvery white. Exquisite and delicate coloring. Imbricated, cup shaped flower of perfect form. Very promising.

\section{JUBILEE (Pleas)}

Flesh white, fading to pure white. Petals narrow and loosely arranged, giving the flower a feathery effect. Large, rather flat rose type. Stems not strong enough to bear the weight of the flowers.

Each $\$ 3.00$

JUDGE BERRY (Brand 1907)

24-8.6 Early

Pink. Semi-rose type. Fine flat flower of large size, Fragrant.

KARL ROSEFIELD (Rosefield 1908)

Each $\$ 5.00$ darge and solidly built. Strong erect grower and good sure bloomer. Very good as a keeper when cut and has no superior as a cut-flower red. One of the very best reds for any purpose.

Each $\$ 1.50$

\section{KATHARINE HAVEMEYER (Thurlow 1921)}

Large, rose-type blooms of flesh pink; guard petals broad and rounded, somewhat notched at the ends, center petals narrow and fringed. Full high center. Sweet fragrance. Midseason to late.

Each $\$ 20.00$

KELWAY'S GLORIOUS (Kelway 1910)

$33-9.8$

Cream white, overlaid with soft rose blush. Very exquisite. Flowers large, full double rose type. One of Kelway's finest productions and one of the finest white peonies.

Each $\$ 10.00$

KELWAY'S QUEEN (Kelway 1909)

$33-8.8$

Flesh pink, center flecked crimson. Beautiful color. Exquisitely fragrant. Tall, strong grower and free bloomer Each $\$ 10.00$

\section{KONIGSWINTER (Goos \& Koenemann)} er.

Large compact double bloom of a soft lilac pink. Tall erect grow-

\section{LADY ALEXANDRA DUFF (Kelway)}

Each $\$ 4.00$

Delicate pale pink fading to white. Very large cup-shaped flower. Main flowers rose type with wide imbricated petals; blossoms from side buds often semi-double. Distinct and charming. Each $\$ 2.00$

\section{LA FRANCE (Lemoine 1901)}

Soft apple blossom pink. Rose type. Large and very beautiful flower when well developed. Fragrant, free bloomer. One of Lemoine's finest early productions.

Each $\$ 4.00$

\section{LA PERLE (Crousse 1885)}

$39-8.5$

Rosy flesh pink with silvery border flecked carmine. Very delicate color and sweet fragrance. Strong, erect and a very charming cutflower. Very appealing.

Each $\$ 1.50$

White petals intersperced with golden stamens. Flat flower resembling a waterlily. Free bloomer in clusters, most attractive when all side buds are permitted to bloom. 


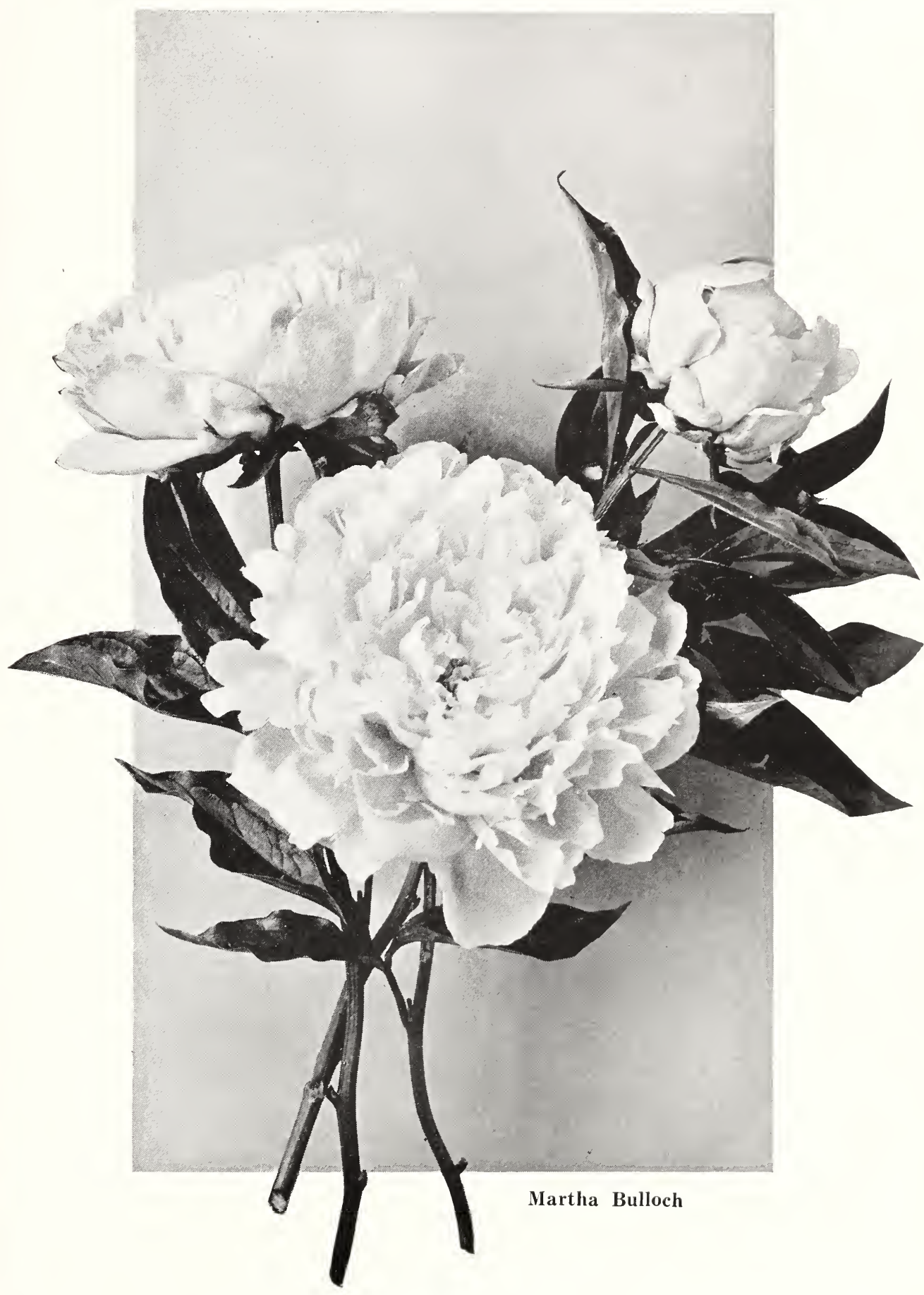


Cream, fading to pure white, slightly splashed carmine. Compact very double flower of large size. Free bloomer.

Each $\$ 1.00$

LA TULIPE (Calot 1872)

$57-7.5$

Blush or very light pink with streaks of carmine on outside petals. Fragrant, globular flowers. Attractive in the opening bud.

Cream white guard petals with bright canary yellow center. Classed as a rose type but in my opinion comes close to bomb type. Considered the nearest approach to a yellow peony.

Each $\$ 4.00$

LE CYGNE (Lemoine 1907)

$56-9.9$

Cream white with a touch of green at the heart. Large rose type flower with petals very much incurved. Considered by many as having attained the highest perfection in a peony. A superb variety and one of the finest in existence.

Each $\$ 8.00$

\section{LIBELLULE (Dessert 1922)}

Flesh. slightly shaded and splashed carmine. Straw and salmon at base of petals. Pleasant fragrance .

Each $\$ 5.00$

LIVINGSTONE (Crousse 1879)

$58-8.1$

Soft pink of medium shade, silver tipped and flecked crimson. Beautiful bright color. Compact double flower held erect on stiff stems. Late, good bloomer.

Each $\$ 1.00$

LONGFELLOW (Brand 1907)

$33-9.0$

Bright deep cherry crimson. Golden stamens surround center petals. Good bloomer. Medium height. Early. Each $\$ 3.00$

\section{LORA DEXHEIMER (Brand 1913)}

$22-8.4$

Deep crimson. shaded deeper at base of petals. Good bloomer. Medium height. Early.

Each $\$ 2.00$

\section{LOVELINESS (Hollis 1907)}

$26-8.8$

Blush pink of exquisite shade. Rose type. Late. One of the best of Hollis introductions.

Each $\$ 3.00$

MME. AUGUST DESSERT (Dessert 1899)

$39-8.6$

Soft pink tinged carmine and flecked crimson. Semi-rose type flower, rather flat. Fragrant free bloomer. Midseason. Each $\$ \mathbf{1 . 5 0}$

\section{MME. BENOIT REVIERE (Riviere)}

Large delicate soft pink, center salmon pink with a collar of narrow vellow petals.

Each $\$ 3.00$

MME. BOULANGER (Crousse 1886)

$31-7.8$

Glossy soft pink tinged lilac, with silvery reflex. Globular and compact bloom of large size. Late midseason. Free bloomer. Desirable cut-flower.

Each $\$ 1.50$

Pale pink fading to white. Very large double and a choice early cut-flower. Erect grower with strong stems. 


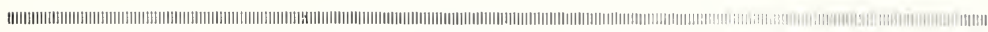

DES MOINES, IOWA

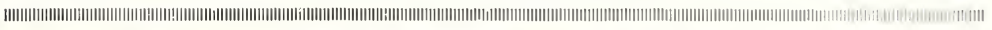

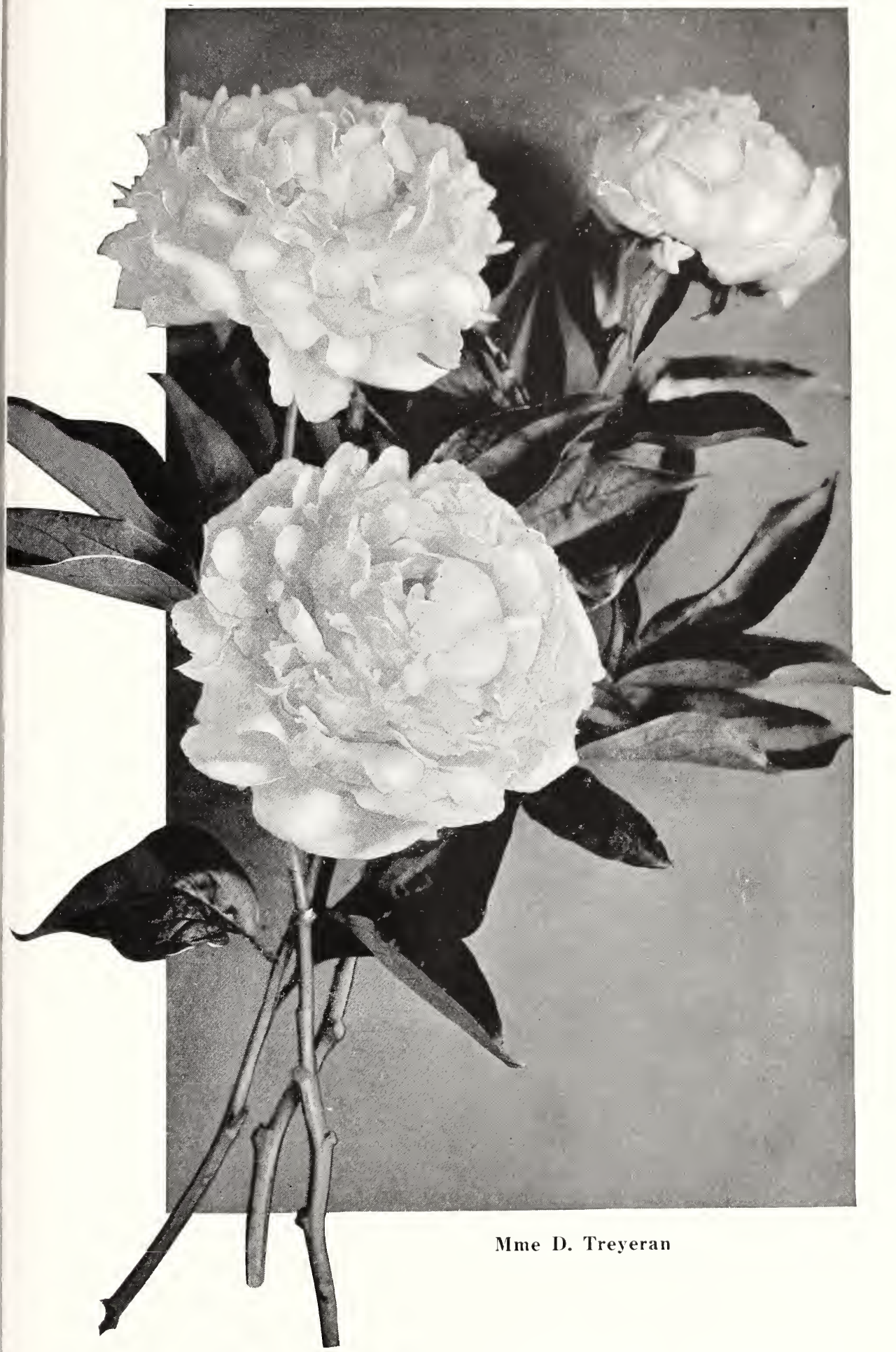


White with blush center tipped carmine. Perfect bomb type. Exquisite fragrance. One of the very popular cut-flower varieties. Early.

Each $\$ 1.00$

\section{MME. D. TREYERAN (Dessert 1899)}

Flesh white splashed lilac and flecked crimson. Elegant flower. Fragrant semi-rose type. Medium height. Early midseason. Each $\$ \mathbf{2 . 0 0}$

MME. DUCEL (Mechin 1880)

$46-7.9$

Pink, of medium shade with silvery reflex. Bomb type, resembling the famous Mons. Jules Elie. Very desirable.

Each $\$ 1.00$

\section{MME EDOUARD DORIAT (Doriat 1924)}

Large globular flower with rounded petals, white with carmine border; golden stamens visible between the petals. Long stiff stems. Beautiful late variety.

Each $\$ 15.00$

MME. EMILE LEMOINE (Lemoine 1899)

$50-8.9$

Milk white of fine form. Delicate and fresh color. Fragrant, tall strong grower. Free bloomer. Very desirable midseason white.

Each $\$ 1.50$

MME. FOREL (Crousse 1881)

$36-7.7$

Glossy pink with silvery reflex and deeper center. Large, compact imbricated rose type. Fragrant. Choice.

Each $\$ 1.00$

MME. JULES DESSERT (Dessert 1909)

$47-9.4$

White, overlaid with delicate tints of pink and buff and splashed carmine. Flowers very large and well formed with long broad petals with a few golden stamens adding to their beauty. Blooms are held erect on tall strong stems. A distinct, beautiful, very popular peony.

Each \$2.50

\section{MADELON (Dessert 1922)}

Silvery pink, lightly tinged carmine. Beautiful, very full imbricated bomb type of bloom of perfect form. A superb late variety.

Each $\$ 8.00$

\section{MARGUERITE GERARD (Crousse 1892)}

$56-8.4$

Hydrangea pink changing to cream white as the flower becomes fully open. Center petals flecked deep carmine. Large, full, semirose type. A high class late peony.

Each $\$ 1.00$

MARIE CROUSSE (Crousse 1892)

$50-8.9$

Delicate shell pink with salmon tints. Bomb type. Tall, erect grower and fragrant free bloomer.

Each $\$ 2.00$

\section{MARIE JACQUIN (Verdier)}

$46-8.3$

Delicate flesh white. Semi-double. One of the best of this type. Distinct and beautiful.

Each \$1.50

MARIE LEMOINE (Calot 1869)

$67-8.5$

Cream of ivory white with occasional carmine tip. Rose type. Late. One of the best of the earlier late whites. Each \$1.50

\section{MARTHA BULLOCH (Brand)}

$67-9.1$

Well formed soft rose-pink. Enormous cup-shaped bloom bourne on strong stems. This peony has an individuality which attracts attention anywhere. Tall, stately variety much in demand. One of Brand's best productions.

Each \$6.00 


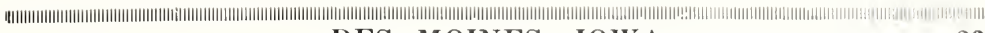
DES MOINES, IOWA

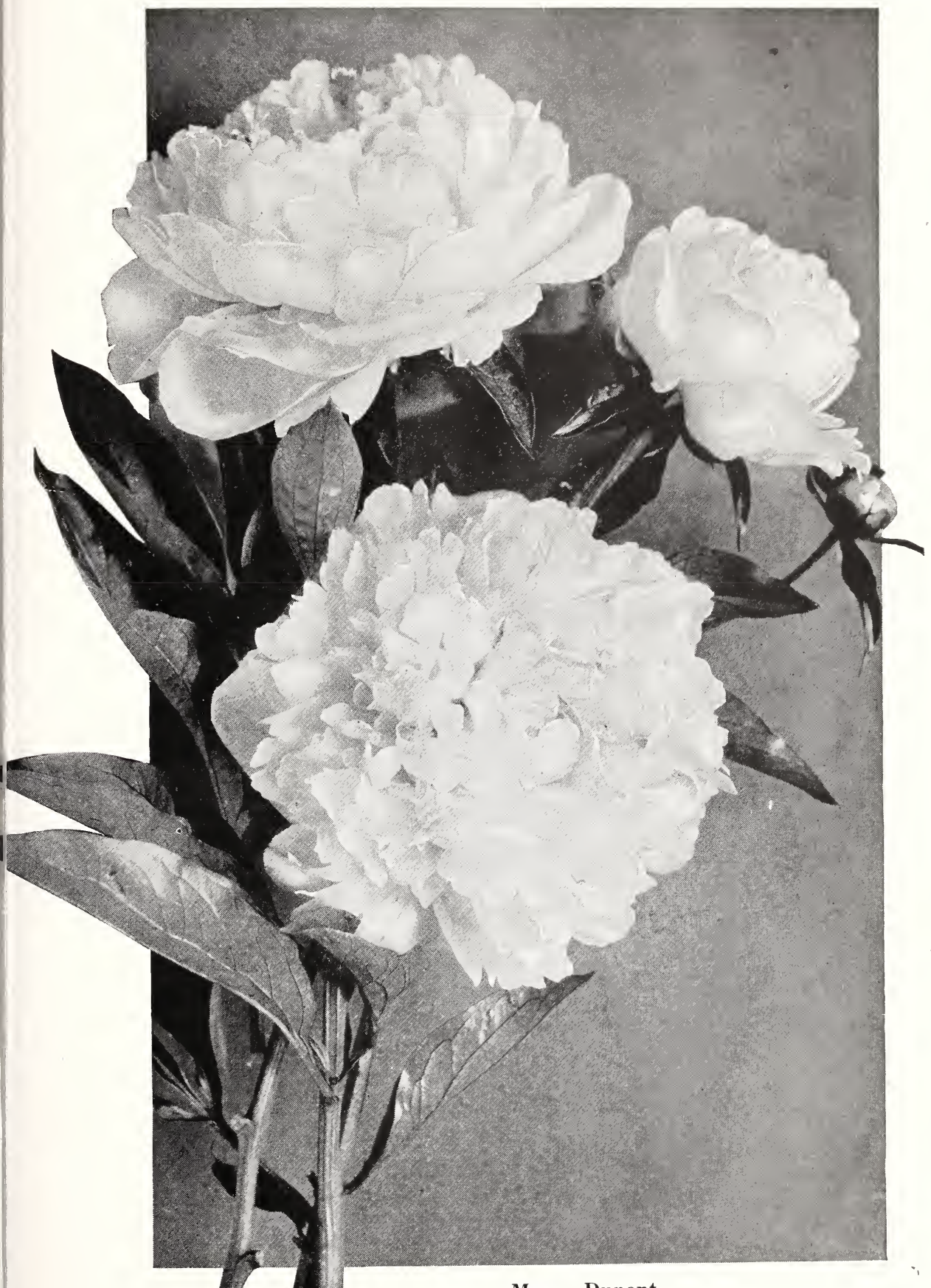

Mons. Dupont 
Deep red with silky sheen. Semi-rose type. Large flower. Mid-

\section{MARY WOODBURY SHAYLOR (Shaylor 1916)}

Each $\$ 2.00$ Clear pink with cream center and golden lights at the heart. Rose type. Large cup-shaped flower of great beauty. Very choice.

Each $\$ 6.00$

MAUD L. RICHARDSON (Hollis 1904)

$21-8.5$

Pale lilac rose, lighter toward center. Rose type. Fragrant. Tall strong grower. Midseason.

Each $\$ 2.50$

\section{MEDIA (Kelway)}

Clear deep pink or rose. Type of good shape. Strong fragrant, midseason bloomer. An extra fine variety in this color. Each 2.00

\section{MILTON HILL (Richardson)}

$63-9.0$

Beautiful shade of clear pink, overlaid with a sheen of very delicate lilac. Very beautiful cup shaped flower of rose type. Very late and very high class.

Each $\$ \mathbf{5 . 0 0}$

\section{MONS. DACHUTRE (Kelway}

Medium shade of soft pink splashed with darker pink throughout the flower. Large and compact bloom with a high center. Very beautiful variety.

Each $\$ 2.00$

\section{MONSIEUR DUPONT (Calot 1872)}

$57-8.3$

Cream or ivory white tipped carmine. Large flat, compact semirose type bloom. Very tall and nearly erect. Late midseason. Each $\$ 1.00$

\section{MONS. JULES ELIE (Crousse 1888)}

$78-9.2$

Glossy lilac pink shading deeper at base of petals, overlaid with a sheen of silver. One of the finest and most perfect pink of bomb type, resembling a huge chrysanthemum. Very desirable for cutflowers.

Each $\$ 1.50$

MONS. MARTIN CAHUZAC (Dessert 1899)

$62--8.8$

Very dark crimson maroon. Semi-rose type. This is the darkest, and the best of the darkest peonies so far introduced. Each $\mathbf{\$ 2 . 5 0}$

MONT BLANC (Lemoine 1899)

$42-8.4$

Milk white, center slightly tinted rose. Rose type. Fragrant free bloomer. Midseason.

Each $\$ 2.50$

\section{MRS. A. G. RUGGLES (Brand 1913)}

Pink, delicately suffused lilac, fading to pure white. Tall, strong growing late variety.

Each $\$ 2.50$

MRS. A. M. BRAND (A. M. Brand 1925)

9.6

Very large pure white of exquisite form. Stems of good length, strong, clean and light green. Late bloomer.

Each $\$ 50.00$

\section{MRS. EDWARD HARDING (Shaylor 1918)}

Large, pure white flower of fine quality. Petals are set close together without overcrowding. Late midseason. (1925 22-9.3) 


\section{MRS. GWYN LEWIS (Kel- way)}

White, very free blooming, fragrant variety. Earliest of all white peonies. Rather dwarf plant. Each $\$ 2.00$

MRS. JOHN M. KLEITSCH (A. M. Brand 1925)

Deep lavender pink. The petals are broad and stiff and the color is not duplicated by any other peony. Late bloomer.

Each $\$ 50.00$

MYRTLE GENTRY (A. M. Brand 1925)

Delicate salmon pink, carrying much of the color of the beautiful Tourangelle. Delightfully fragrant. Late. Each $\$ 50.00$

NANCY DOLMAN (Vories 1924)

Pink. Rose type. Very large plant and flower. Late. Each $\$ \mathbf{5 0 . 0 0}$

\section{NANETTE (Doriat 1924)}

White. Large cup-shaped flower. Very early. Strong erect habit. Each $\$ 8.00$

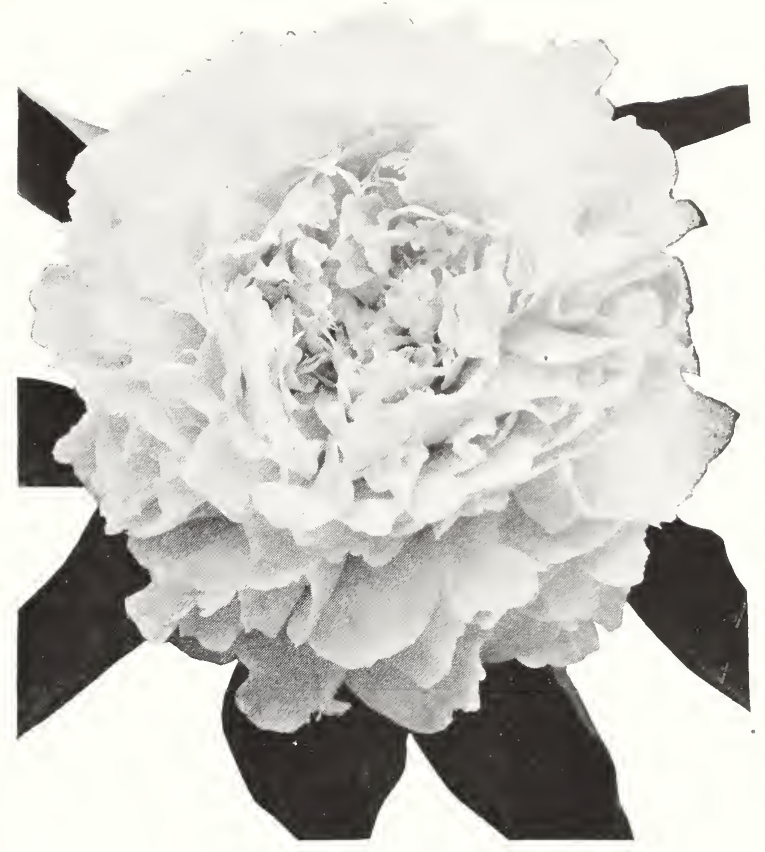

La France

\section{NIMBUS (Andrews 1923)}

White, deepening at center to pale blush buff. Late, tall strong grower. Very fine cup-shaped flower.

NYMPHEA (Thurlow 1919)

Delicate creamy white. Large flat flowers with wide silky petals notched at tips. Yellow stamens in center. Semi-rose type. In my opinion the most beautiful peony of the "waterlily" type so far introduced.

Each $\$ 3.50$

OCTAVIE DEMAY (Calot 1867)

$42-8.5$

Blush or very light pink fading to white tipped carmine. Dwarf, very free blooming early variety. Erect. Each $\$ 1.00$

PERETTE (Dessert 1921)

White, slightly tinged flesh and straw yellow. Petals intermixed with golden stamens. Fragrant, free bloomer. Each $\$ 2.00$

PHILIPPE REVOIRE (Riviere 1911)

$28-9.2$

Very dark crimson. Rose type. Cup-shaped flower with narrow stiff incurved petals. Sweet fragrance. Midseason to late. Each $\$ 15.00$

PHOEBE CAREY (Brand 1917)

$21-8.8$

Soft lavender pink, center shaded darker. Tall, strong grower. Late. Fragrant. Free bloomer.

Each $\$ 5.00$

PHYLLIS KELWAY (Kelway 1908)

$22-9.0$

Pale pink with lighter center. Very delicate beautiful color. Midseason. Very good.

Each $\$ 8.00$

POLYPHEMUS (Kelway)

Medium shade of soft pink. Medium height, strong grower. Midseason bloomer.

Each $\$ 1.00$ 


\section{PRESIDENT WILSON (Thurlow 1918)}

Soft rose pink changing to shell pink as flower opens. Guard petals sometimes show crimson markings. Center petals short, gradually increasing in length outward, producing a cup like effect. Fragrant, late, very beautiful variety.

Each $\$ 30.00$

\section{PRIMEVERE (Spring) (Lemoine 1907)}

Outer petals sulphur white, center deep sulphur yellow. Bomb type. Midseason. Primevere and Laura Dessert resembles each other a great deal. Laura Dessert blooms a little earlier and has a stronger stem. They are both interesting, valuable and beautiful. The nearest to yellow in peonies.

Each $\$ 2.50$

\section{REINE HORTENSE (Calot 1858) 40-8.7}

Beautiful uniform light pink, center flecked crimson. Fragrant, semi-rose type. One of the best all around pink peonies. Midseason. This and Sarah Bernhardt are pink peonies of such superlative quality and value that I strongly recommend them for all purposes. They are good for landscape planting, and cutflower production and are very splendid for the home garden. Reine-Hortense blooms earlier than Sarah Bernhardt. Reine Hortense.

Each $\$ 2.00$

RICHARD CARVEL (Brand 1913)

$36-8.3$

Bright crimson. Large, early. Bomb type. Tall strong grower and free bloomer. Brilliant peony much in demand. Each $\$ 3.00$

ROSA BONHEUR (Dessert 1905)

$46-9.0$

Brilliant light pink of even shade. Compact, imbricated bloom of fine shape. Beautiful, erect dwarf variety. Late. Another fine pink. Each $\$ 3.00$

\section{ROSETTE (Dessert 1918)}

Silvery flesh, shading to salmon at base of petals and flecked crimson on border. Flower of fine shape like a Captain Christy rose. Early. Erect.

Each $\$ 3.00$

\section{RUBRA SUPERBA (Richardson)}

Rich brilliant crimson without stamens. Very late. Individual flowers very fine. Its one fault being that it is not a free bloomer.

\section{RUTH BRAND (Brand 1907)}

Soft lavender pink splashed with deeper lavender. Large, compact, fragrant flower. Midseason.

Each $\$ 1.50$

\section{SARAH BERNHARDT (Lemoine 1906)}

$49-9.0$

Clear, deep apple blossom pink with silver tipped petals. Very strong grower, bearing large, very beautiful flowers in clusters. Fragrant, late midseason. One of the finest pinks for all purposes. Our stock of this variety is very strong, clean and healthy. Each $\$ 2.00$

\section{SARAH K. THURLOW (Thurlow 1921)}

Broad rounded guard petals of flesh white on pearly white, with deeper heart of soft blush with faint salmon shades. Fragrant. Stiff stems and good foliage. Late.

Each $\$ 20.00$

\section{SOLANGE (Lemone 1907)}

Waxy white, suffused with shades of buff and with a glow of golden lights at the heart. Very beautiful distinct color. Flowers extra large with broad rounded petals of fine form. Late midseason. One of the finest peonies in existence. 

SOUV. DE EXPOSITION UNIVER-
SELLE (Calot 1867)

Deep satiny pink, with slight silvery reflex. Flat rose type. Very good bloomer. Late midseason. Another good old variety. Each $\$ 1.00$

SOUV. DE FRANCOIS RUITTON (Riviere)

Bright cherry pink, dark carmine at base of petals. Rose type. Large globular flowers bourne in profusion. Good for cutting.

Each $\$ 3.00$

\section{SOUV. DE LOUIS BIGOT (Des- sert 1913) 22-9.1}

Distinct shade of rich salmon pink with silvery lights. Rose type. Late midseason. Extra fine and growing in popularity. Each $\$ 5.00$

\section{SUZETTE (Dessert 1911)}

Brilliant rose-pink interspersed with golden stamens. Semi-rose type. Profuse bloomer. Midseason. Fine for garden effect. Each \$2.00

\section{THERESE (Dessert 1904) \\ $71-9.8$}

Brilliant bright pink with exquisite lavender tints, center of flower lighter. Rose type. Fragrant midseason bloomer. Large, yet exquisitely lovely. One of the most beautiful peonies in existence. Has srobably won more prizes at peony shows than any other variety. One of the high numbers among peonies and cheap at the price Each $\$ 3.00$

TOURANGELLE (Dessert 1910)

$49-9.4$

Pearl, or cream white overlaid with delicate shades of pink, salmon and buff. Rose type. Very beautiful cup-shaped flowers with a color of most exquisite beauty. A real gem. Stems rather weak and should have support. $\quad$ Each $\$ 3.00$

TRIUMPH DE LILLE (Calot 1865)

$42-7.8$

Hydrangea pink splashed with crimson tints. Delicate pleasing color. Semi-rose type.

Each $\$ 1.00$

VENUS (Kelway)

$50-8.3$

Pale pink, uniform color. Well formed flower suitable for cutflower production. Fragrant. Early midseason. $\quad$ Each $\$ 1.50$

\section{VICTOIRE DE LA MARNE (Dessert 1915)}

"Velvet purple red, with silvery reflex. Very bright coloring. Large, globular blooms. Midseason.

Each $\$ 3.00$

\section{WALTER FAXON (Richardson)}

$48-9.3$

Clear pink. Rose type. One of the purest shades of pink in any peony. Very beautifully formed flower. Late midseason. Each $\$ \mathbf{1 . 0 0}$ 


\section{Single and Japanese 羽enies}

\section{SINGLE PEONIES}

These are of the form of a wild single rose, having a single row of petals surrounding a tuft of golden stamens.

ALBIFLORA. The Bride.

Pure white large flower. Plant tall and robust but inclined to slightly droop.

Each $\$ 1.00$

AUSTIN CHAMBER-

LAIN (Kelway)

Single red, large flower. Medium tall plant. Early free bloomer

Each $\$ 2.00$

DEPARTING SUN

Single red. Large flowers on tall strong stems.

Each $\$ 2.00$

INNOCENCE (Hollis)

Light lilac rose with canary yellow center. Tall, erect and a good bloomer.

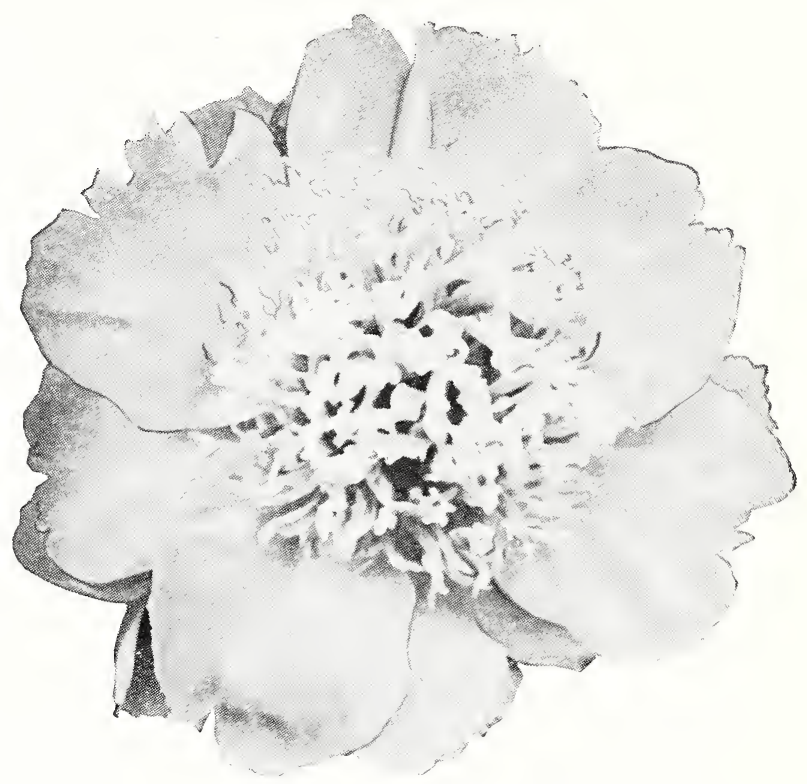

Each $\$ 3.00$

\section{MARGUERITE DESSER' $T$ (Dessert 1913)}

Very large single bloom; pure white blotched carmine with a crown of golden stamens. Very good.

Each $\$ 4.00$

OTHELLO (Dessert 1908)

Broad carmine-purple petals, golden stamens. Each $\$ 1.00$

PRIDE OF LANGPORT

Fine single pink.

Each $\$ 5.00$

STANLEY (Kelway)

Single crimson, golden stamens.

Each $\$ 1.00$

\section{JAPANESE PEONIES}

The Japanese peonies resemble the single peonies in that they have wide guard petals but instead of a tuft of pollen bearing stamens in the center they have a tuft of narrow petaloids.

\section{A'TTRACTION (Hollis)}

Guard petals deep Tyrian rose, center petaloids tipped yellow.

Each $\$ 2.00$

\section{CATHEDRAL}

Deep pink petals, stamens partly transformed making a soft creamy yellow center. Odd and beautiful.

Each $\$ 2.00$

\section{EXQUISITE (Japan)}

Beautiful white from Japan, center yellow. Guard petals of fine form and good substance.

Each $\$ 5.00$ 


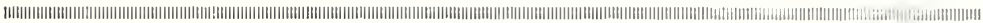

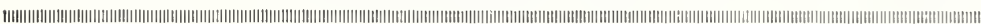

GYPSIE (Hollis)

Unique and beautiful pink.

Each $\$ 2.00$

HENRI POTIN (Doriat 1924)

China pink, tinted carmine. Big tuft of filmentous petals of the same color at the base, gradually turning to white and vivid yellow at the tips.

Each $\$ \mathbf{5 . 0 0}$

\section{MIKADO (Japan)}

One of the best red Japs. First exhibited in America at the Chicago World's Fair in 1893 by the Japanese government. Outer petals wide, dark crimson encircling a cushion of golden petaloids crimson edged and golden tipped.

Each $\$ 2.50$

\section{RASHOOMON (Japan)}

Deep rose red with a tuft of crinkled golden filamental petals in center.

Each $\$ 5.00$

\section{TORO NO MAKI (Japan)}

Lilac white guard petals surrounding a center of amber yellow. One of the very good Japanese peonies.

Each $\$ 5.00$

\section{PEONIES IN THE LITTLE GARDEN}

This is the title of one of the most delightful books ever written on the peony. Mrs. Edward Harding is the author and Mrs. Francis King is editor Mrs. Francis King says: "With this book anyone can order roots judiciously, plant intelligently, compare, collect, cut, show and, best of all, enjoy the peony to the utmost." We recommend this book to everyone interested in peonies. Sent postpaid for $\$ 1.75$.

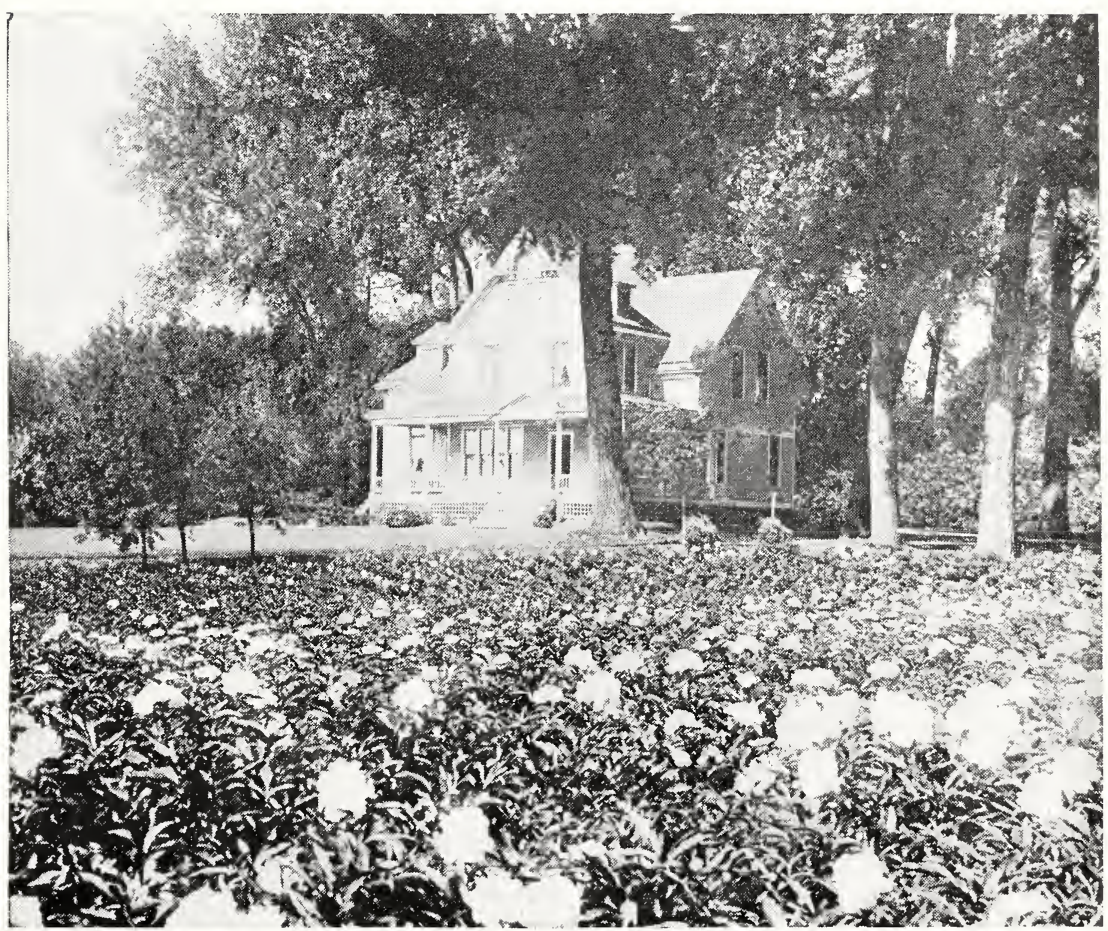




\section{American 羽ony Society}

Your enjoyment of peonies will be much enhanced if you are a member of the American Peony Society and receive the bulletins and literature of the Society. Full information will be sent on request.

Over every home, hamlet, and farm there hangs a divine ideal of what the place should be, just as the plan of the stately building hangs in the office of the architect. Pull down the plan and work to it and you will be amazed at the result. All around us are surprises of loveliness, if we would only let them reveal themselves. How rich we would be if we could reach out and take our own!

-C. S. Harrison.

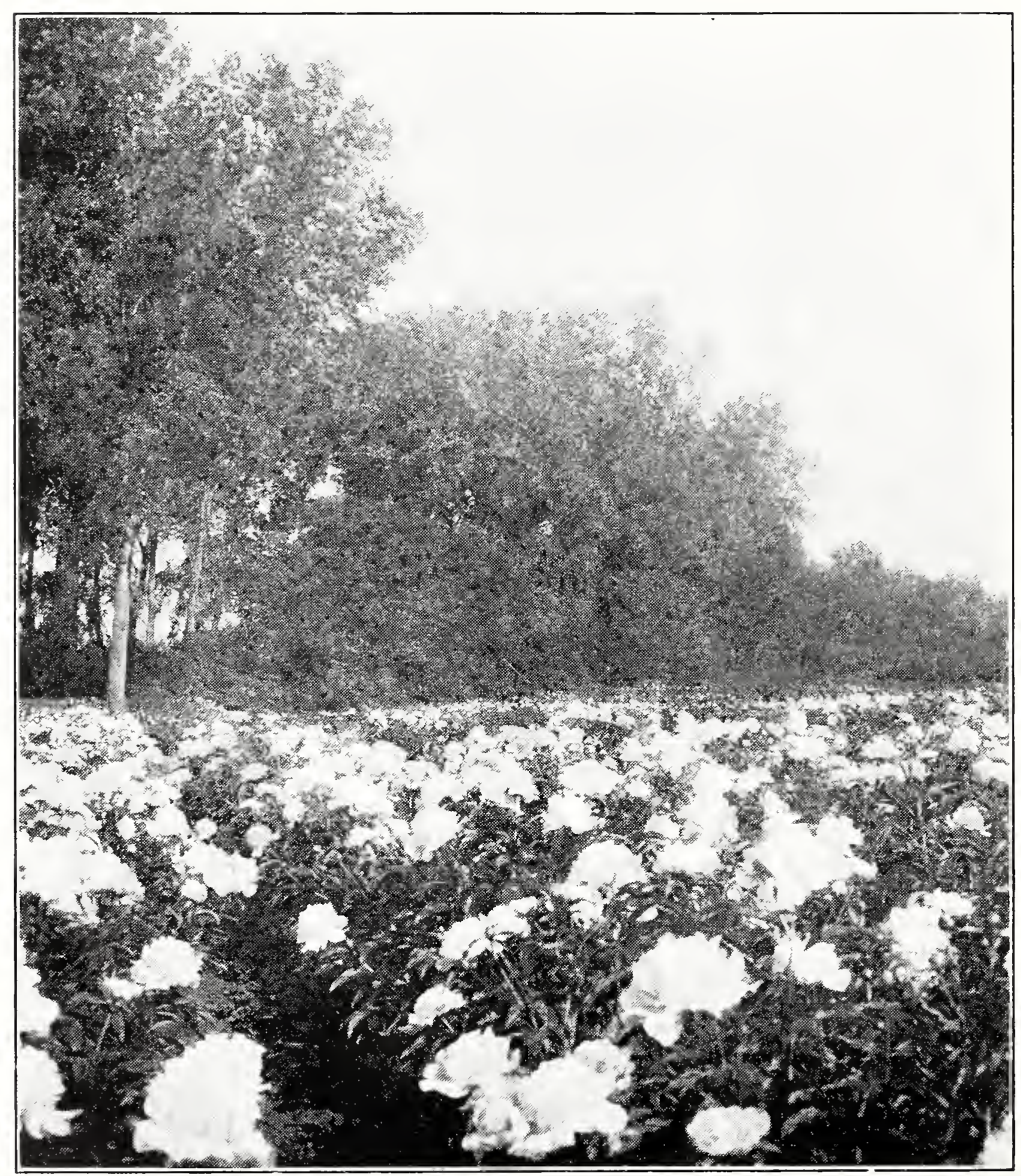




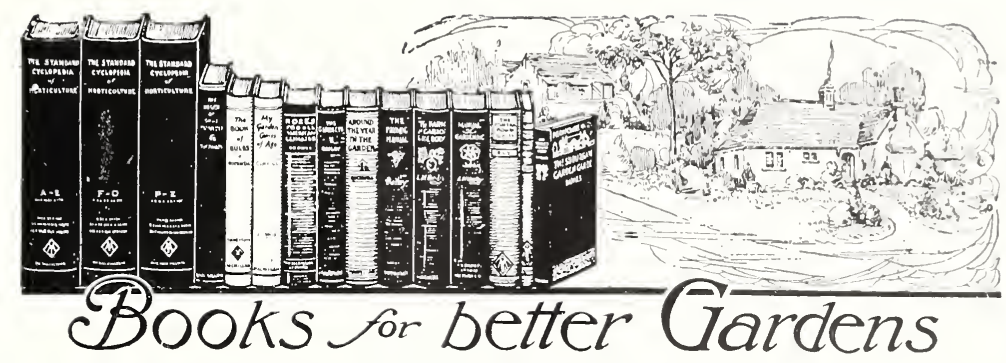

The Book of Bulbs, by F. F. Rockwell. We can recommend this as the most complete and practical book on bulbs for American conditions. Pictures and text show and tell just how to make the most from bulbs in your garden, both outdoors and inside the home. In addition to the more widely-grown bulbs, the book introduces others not so well-known that will bring new beauty to your garden and new pleasure to your gardening. Ill., 264 pp.,

$\$ 3.00$

Home Flower-Growing, by E. C. Volz. This book is a real flower garden encyclopedia! It contains all the information necessary for the making of a successful garden, complete in every respect. Descriptions of the various plants show you how to lay out the garden to secure proper combinations of color and height. How to organize and manage a garden club and community flower show. Ill., 384 pp.,

ROCK GARDENS, by F. F. Rockwell. In a small space-or a large one-you can build a rock garden that will be a continual beauty spot through all the growing seasons. This practical book shows just how to go about constructing one of these gardens at small cost and for the greatest enjoyment. Describes differen' types of rookeries, tells what soil, climate, and location is needed, how to construct, and what plants to use. Ill., 90 pp., $\$ 1.00$

Evergreens for the Small Place, by F. F. Rockwell. All the information you need to make the most of evergreens about your home is in this handy book, written by one who is himself a home owner and a garden maker of long experience. It tells the uses, characteristics, and types of small or dwarf evergreens, and details of their planting, transplanting, and general care. Ill., 90 pp., $\$ 1.00$

The Rose in America, by J. H. McFarland. Beautifully illustrated in color and sepia and replete with practical suggestions, this new and enlarged edition has an important place on every rose fancier's book shelf. Ill., 233 pp.,

$\$ 3.00$

Shrubs, by F. F. Rockwell. Here is brief but complete and usable information on the best ways to improve the beauty and value of your home with shrubs. Tells what to use for different combinations and effects, and sow to plant, water, mulch, prune and care for shrubs. Ill., 76 pp.,

$\$ 1.00$

Garden Cinderellas: How to Grow Lilies in the Garden, by book for the home garden maker. Gives the native home, flower Helen M. Fox. This is the best and the only complete American lily and foliage characteristics, season of bloom, propagation methods, and culture of every known lily. Full of practical and valuable hints for garden practice and new ideas for indoor and outdoor use of these beautiful flowers. Illustrated with color plates and numerous halftones, $280 \mathrm{pp}$.,

$\$ 5.00$

Making Your Own Market, by R. Lord and T. Delohery. Seventy actual experiences in selling farm, garden, and home products directat roadside stands, at home, by retail routes, and by mail. Covers dozens of different products and a wide variety of sales methods. Ill., 112 pp.,

$\$ 1.25$

THE GENTON REVIEW SHOP, FOWLER, IND 


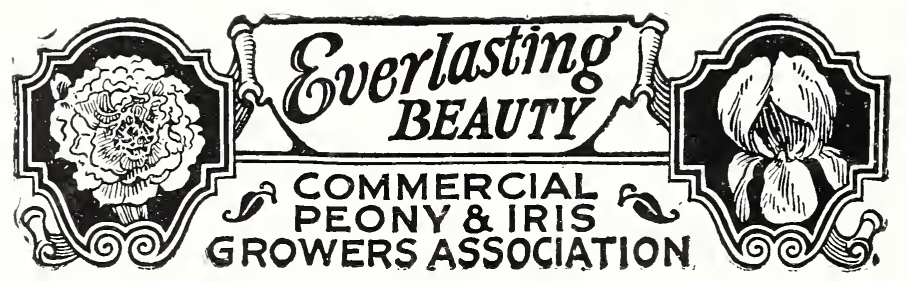

